\title{
EFFECT OF NITROGEN SOURCES AND WEED MANAGEMENT OPTIONS ON WEED GROWTH AND CROP YIELD OF TRANSPLANT AMANRICE
}

\author{
R. Ghosh ${ }^{1}$, M. Salim ${ }^{1}$ and S. Ahmed ${ }^{1,2}$ \\ ${ }^{1}$ Agronomy Division, Bangladesh Agricultural University, Mymensingh, Bangladesh \\ ${ }^{2}$ International Rice Research Institute, Bangladesh \\ "Corresponding author's email: s.ahmed@irri.org
}

Key words: Nitrogen source, sustainable crop production, herbicide, weed growth, rice yield.

\begin{abstract}
A field study was conducted at the Agronomy research field of Bangladesh Agricultural University, Mymensingh, during the period of July to December, 2013 to evaluate the sources of nitrogen and weed management options on weed growth and rice yield. The experiment included four nitrogen sources (100\% cowdung, 100\% prilled urea, 100\% urea super granule, $50 \%$ cowdung $+50 \%$ prilled urea) and four weed management options (weedy, application of herbicide at 3 DAT, application of herbicide at 3 DAT followed by hand weeding at 21 DAT and weed free). Sources of nitrogen and weed management options had significant effect on tiller number, biomass, SPAD value, panicle number, number of florets panicle ${ }^{-1}$, grain and straw yield, and weed biomass. The highest grain yield $\left(5.40 \mathrm{t} \mathrm{ha}^{-1}\right)$ was found in the treatment of $50 \%$ cowdung + $50 \%$ prilled urea with combination of season long weed free. Although $100 \%$ prilled urea had significantly similar grain yield to $50 \%$ cowdung $+50 \%$ prilled urea, however, across the weed management options, 100\% urea super granule and 100\% cowdung had 15 and 27\% lower grain yield. Irrespective of the weed management options, $100 \%$ prilled urea had always higher weed biomass and 100\% USG, 50\% cowdung + $50 \%$ prilled urea, and 100\% cowdung had 46, 35 and 19\% lower weed biomass, respectively, compared with $100 \%$ prilled urea. In terms of rice yield and weed management, combined application of organic and inorganic source of nitrogen is better than only chemical or only organic source and pre-emergence herbicide followed by one hand weeding for transplanted aman rice.
\end{abstract}

\section{Introduction}

In Bangladesh, there are three distinct rice growing seasons such as aus, aman and boro. Among them, aman covers more than half of the rice area accounting 5.61 million hectares with a production of 12.89 million tons of rice (BBS, 2013). It was always reported that in aman season yield gap between farmers and researcher is always higher and it is mainly due to imbalaced use of fertilizer and lack of inadequate pest management (Salam et al., 2004). Application of inorganic $\mathrm{N}$ fertilizer is considered to be most effective measures for improving rice production. Unfortunately, fertilizer nitrogen $(\mathrm{N})$ is not utilized efficiently in the world agriculture and the recovery of $\mathrm{N}$ in cereals, at global level is reported to be less than $40 \%$ (Raun and Johnson, 1999; Raun et al., 2002). Inorganic prilled urea (PU) is the principle source of $\mathrm{N}$ for rice production in Bangladesh; however, in aman season crop can utilize less than $40 \%$ of applied nitrogen (Ali et al., 2006). This is due to low recovery efficiency of $\mathrm{N}$ is associated with its high losses by leaching, denitrification, and volatilization (Fageria and Baligar, 2005). Urea super granule (USG) is an alternate source of nitrogen fertilizer and becoming popular to the farmers. 
Weeds are the greatest yield-limiting pest to rice production (Ahmed and Chauhan, 2014). Global yield losses due to pests have been estimated approximately 40\% where weeds caused the highest loss which is around 32\% (Rao et al., 2007). The weather condition of aman rice season in Bangladesh is highly favorable for the enormous growth of weeds (Ahmed and Chauhan, 2015). The rice crops are severely infested with weeds and can reduce the grain yields by $16-48 \%$ for aman rice (IRRI, 1998). Therefore, weed management is an important issue to obtain higher grain yield and better economic return. Weeding in Bangladesh commonly done by manually. In the large scale rice farming, herbicide based weed management has become viable option high costs of labor (Anwar et al., 2012; Singh et al., 2006). Although herbicides are more reliable tools to manage weeds but sole dependence on herbicide may develop resistant biotypes and negative impacts on environment (Fischer et al., 2000). Therefore, effective weed management needs an integrated approach such as appropriate land preparation, use weed seed free tillage instruments, vigorous cultivars, planting density, row spacing, water management, fertilizer management, manual or mechanical weeding and herbicides (Chauhan et al., 2015). Nitrogen is a key nutrient which regulates the growth and development of plants and plays a significant role in the competitive balance between weeds and crops (Raun and Johnson, 1999). Therefore, this study was undertaken to investigate the effect of sources of nitrogen fertilizer and weed management options on the crop and weed growth and crop yield of transplanted aman rice.

\section{Materials and Methods}

The experiment was conducted at the agronomy field, Bangladesh Agricultural University, Mymensingh, during the periods from July to December 2013. The experimental field was located at $7524^{\prime} \mathrm{N}, 5090^{\prime} \mathrm{E}$ and altitude of $18 \mathrm{~m}$ above the mean of sea level. The experimental site belongs to Agro-ecological Zone 9 of Old Brahmaputra Floodplain. The land was medium high and well drained, the soil was silty loam and low fertility level. The $\mathrm{pH}$ value of the soil was 6.7 and average organic matter content 1\%. The experimental area was characterized by high temperature (average mean maximum temperature $35^{\circ} \mathrm{C}$ ), high humidity and heavy precipitation with occasional gusty winds in Kharif season (April to October) and scanty rainfall associated with moderately low temperature during the Rabi season (November to March). Historically the experiment site is under rice-fallow-rice cropping system. The experiment consists of four nitrogen sources [100\% cowdung (10 t ha $\left.\mathrm{t}^{-1}\right), 100 \%$ prilled urea (220 kg ha $\left.{ }^{-1}\right), 100 \%$ urea super granule $\left(65 \mathrm{~kg} \mathrm{ha}^{-1}\right)$, and $50 \%$ cowdung $\left(5 \mathrm{t} \mathrm{ha}^{-1}\right)+50 \%$ prilled urea (110 kg ha-1)] as main plot treatments and four weed management options [weedy, weed-free, herbicide (oxadiargyl $80 \mathrm{~g}$ ai ha-1), herbicide (oxadiargyl $80 \mathrm{~g}$ ai ha-1) followed by one hand weeding ( $1 \mathrm{HW}$ at 21 days after transplanting (DAT))] as sub-plot treatments. The experiment included in a split-plot design with three replications.

Full dose of TSP, MOP, gypsum, and zinc sulphate were applied at the rate of $15,48,12$, and $2.2 \mathrm{~kg} \mathrm{ha}^{-1}$ of $\mathrm{P}, \mathrm{K}, \mathrm{S}$, and $\mathrm{Zn}$, respectively. Cowdung was applied according to treatment and leveling only those plots which received cowdung. Thirty-five-day aged nursery seedling of var. BRRI dhan 49 was transplanted on 27 July 2013 using $20 \mathrm{~cm}$ x $15 \mathrm{~cm}$ and three seedlings hill ${ }^{-1}$. Prilled urea was applied three equal splits at 15, 35 and 55 DAT. Urea super granules was manually dibbling, one granules in the middle of four hills at 7 DAT. Experiment plots irrigated individually and kept continuous standing water up to 10 days before harvest. Disease and insect management were need based. The plots which received herbicides, applied at 4 DAT. One manual weeding plots were weeding at 21 DAT. Weedy plots allowed season long weed infestation and weed-free plots were kept completely weed-free by 4 times manual weeding. 
Plant height was measured at 35 DAT and at flowering from randomly selected 20 hills. Rice tiller was counted from fixed 8 hills which covered $0.5 \mathrm{~m}^{-2}$ areas. To evaluate the weed management options on weed groups (i.e., grass, broadleaf, and sedge), weed biomass was measured at 35 DAT and flowering from two randomly selected quadrates of $40 \mathrm{~cm} \times 40 \mathrm{~cm}$. Weeds were separated by group, and their biomass was measured after oven drying the samples at $70{ }^{\circ} \mathrm{C}$ for $72 \mathrm{~h}$. SPAD value was measured using SPAD meter from randomly selected 10 hills. One top most fully expanded leaf was selected from each hill and measured from tip, middle and base of the leaf. When $80-90 \%$ of the grains became golden yellow, the crop was considered to be matured. Grain yield was converted to t ha ${ }^{1}$ at $14 \%$ moisture content. Data were analyzed using ANOVA to evaluate differences between treatments and the means were separated using least significant differences (LSD) at the 5\% level of significance (Crop Stat 7.2; International Rice Research Institute, Philippines).

\section{Results and Discussion}

\section{Plant height}

Plant height did not influence by the interaction of nitrogen sources and weed management options, however, influenced by their individual effect (Figure 1). The highest plant height (53.8 $\mathrm{cm}$ ) was recorded when plots received $50 \%$ cowdung $+50 \%$ prilled urea AT 35 DAT. Plot received with $100 \%$ prilled urea had statistically similar plant height to $50 \%$ cowdung $+50 \%$ prilled urea.

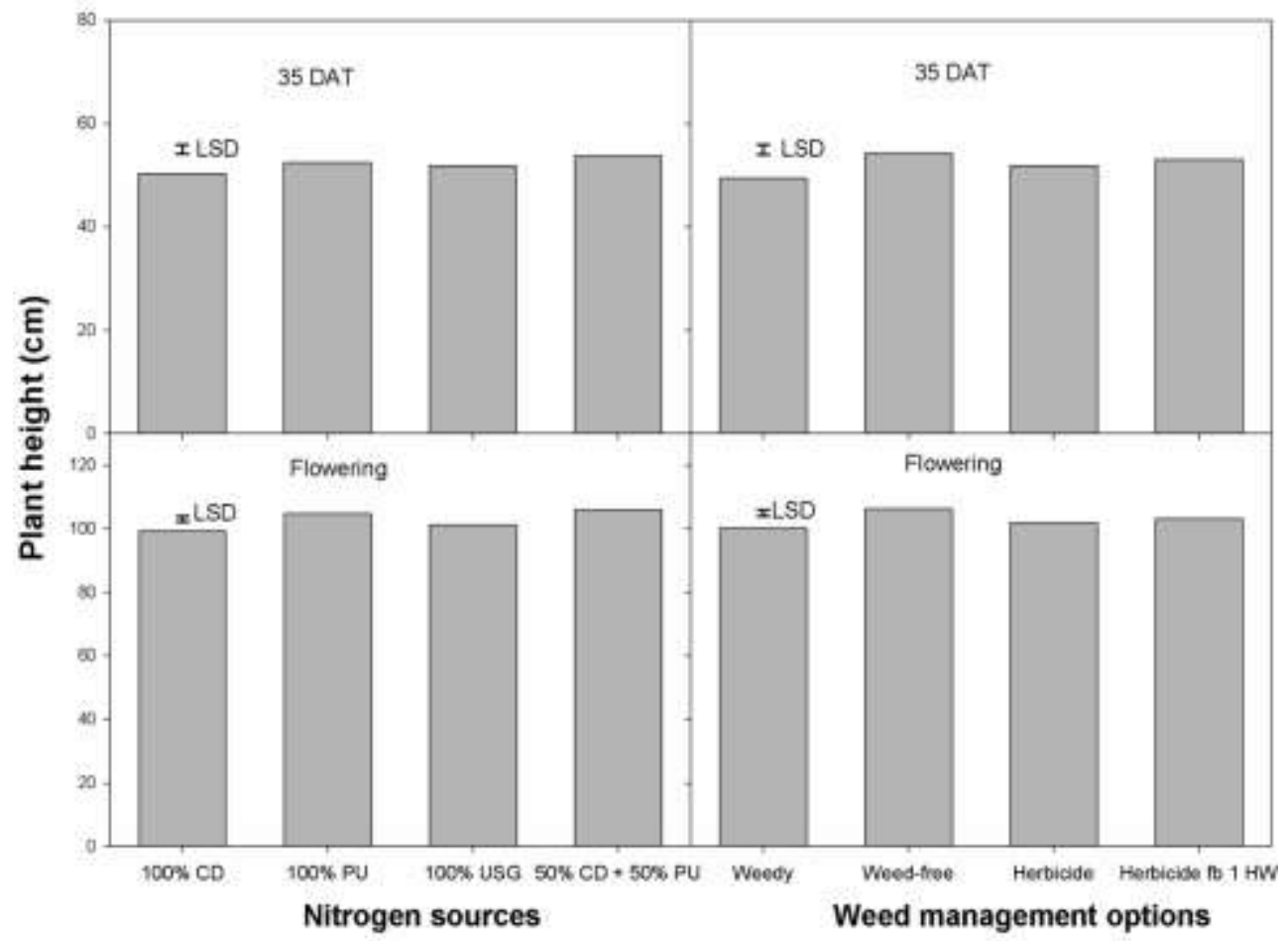

Fig.1. Effect of nitrogen sources and weed management options on plant height at 35 DAT and at flowering. CD (Cowdung), PU ( Prilled Urea), USG, (Urea Super Granule). Vertical bars indicate LSD at 5\% level of significant. 
Ghosh et al.

The lowest plant height $(50.3 \mathrm{~cm})$ was recorded from plots received $100 \%$ cowdung. in case of weed management options, the maximum plant height $(54.2 \mathrm{~cm})$ was recorded from the weed-free plots followed by one hand weeding while lower $(49.4 \mathrm{~cm})$ plant height in weed control (Figure 1). At flowering, plant height was maintained a similar trend to 35 DAT.

\section{Rice tiller}

Tiller density significantly influenced by the interaction of nitrogen sources and weed management options (Figure 2). Tiller density at 35 DAT had higher than at flowering and it was due to some tiller mortality after panicle formation. Similar results were reported by Hasanuzzaman et al., 2009; Sudhir-Yadav et al., 2011. Tiller density was higher when plots received nitrogen source of $50 \%$ cowdung $+50 \%$ prilled urea with season long weed-free. The $100 \%$ prilled urea had significantly similar tiller density to $50 \%$ cowdung $+50 \%$ prilled urea treatment. The plots received nitrogen source 100\% cowdung had always lower tiller density than the nitrogen sources of 50\% cowdung $+50 \%$ prilled urea and $100 \%$ prilled urea, however, almost similar to $100 \%$ USG. The lowest panicle density was recorded in season long weedy treatment. The plots which received only herbicide had significantly higher tillers than the weedy treatment.

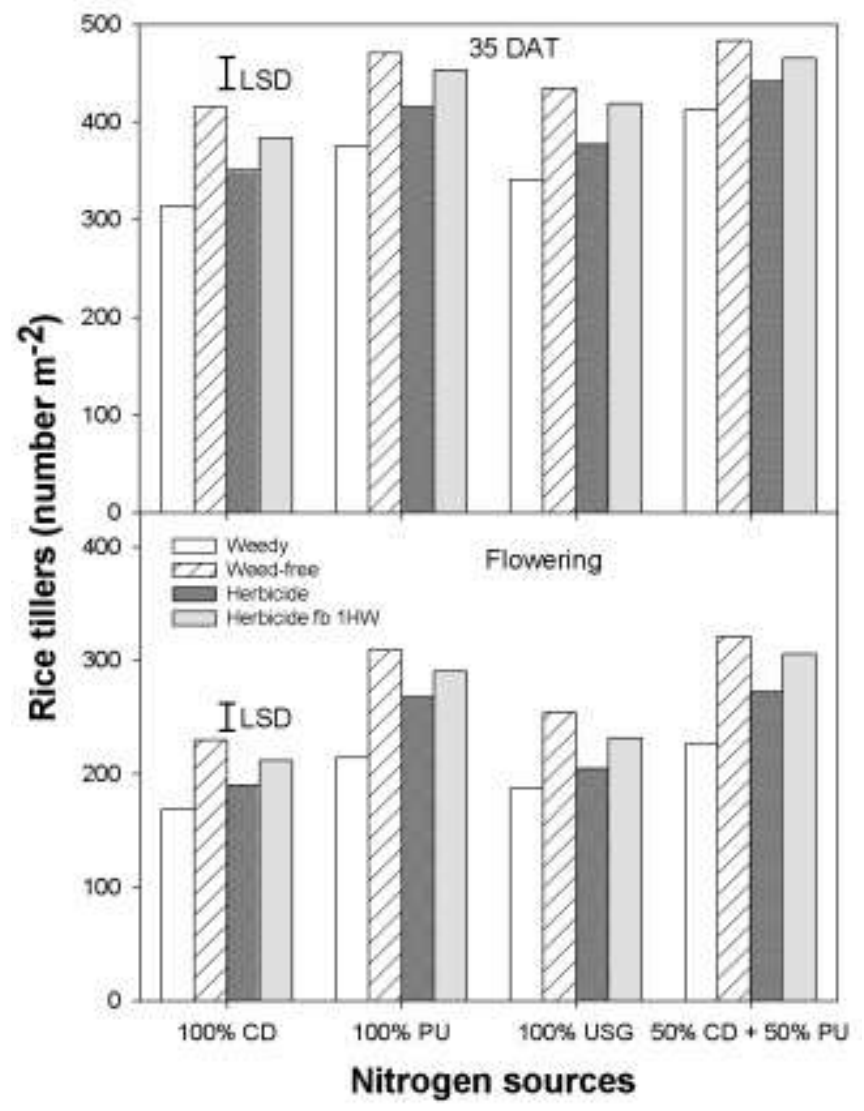

Fig. 2. Effect of nitrogen sources and weed management options on rice tiller (number $\mathrm{m}^{-2}$ ) at 35 DAT and at flowering. CD (Cowdung), PU (prilled urea), USG (Urea Super Granule). Vertical bars indicate LSD at 5\% level of significant. 


\section{Rice biomass}

There was an interaction between nitrogen sources and weed management options on rice biomass (Figure 3). Irrespective of the nitrogen sources, weed-free treatment had always higher rice biomass than any other weed management options. Across the nitrogen sources, herbicide followed by $1 \mathrm{HW}$ treatment had 6-13\% lower rice biomass than the weed-free treatment, however, 4-19\% higher than the treatment which received only herbicide. Season long weedy treatment had always lower rice biomass. In case of nitrogen sources, 50\% cowdung $+50 \%$ prilled urea had always higher rice biomass. At 35 DAT, nitrogen source of $100 \%$ prilled urea had similar rice biomass to $50 \%$ cowdung $+50 \%$ prilled urea, however, at flowering it was lower. Irrespective of the weed control options, 100\% USG had significantly lower rice biomass than the 50\% cowdung $+50 \%$ prilled urea and 100\% prilled urea, however, significantly higher than the nitrogen source $100 \%$ cowdung.

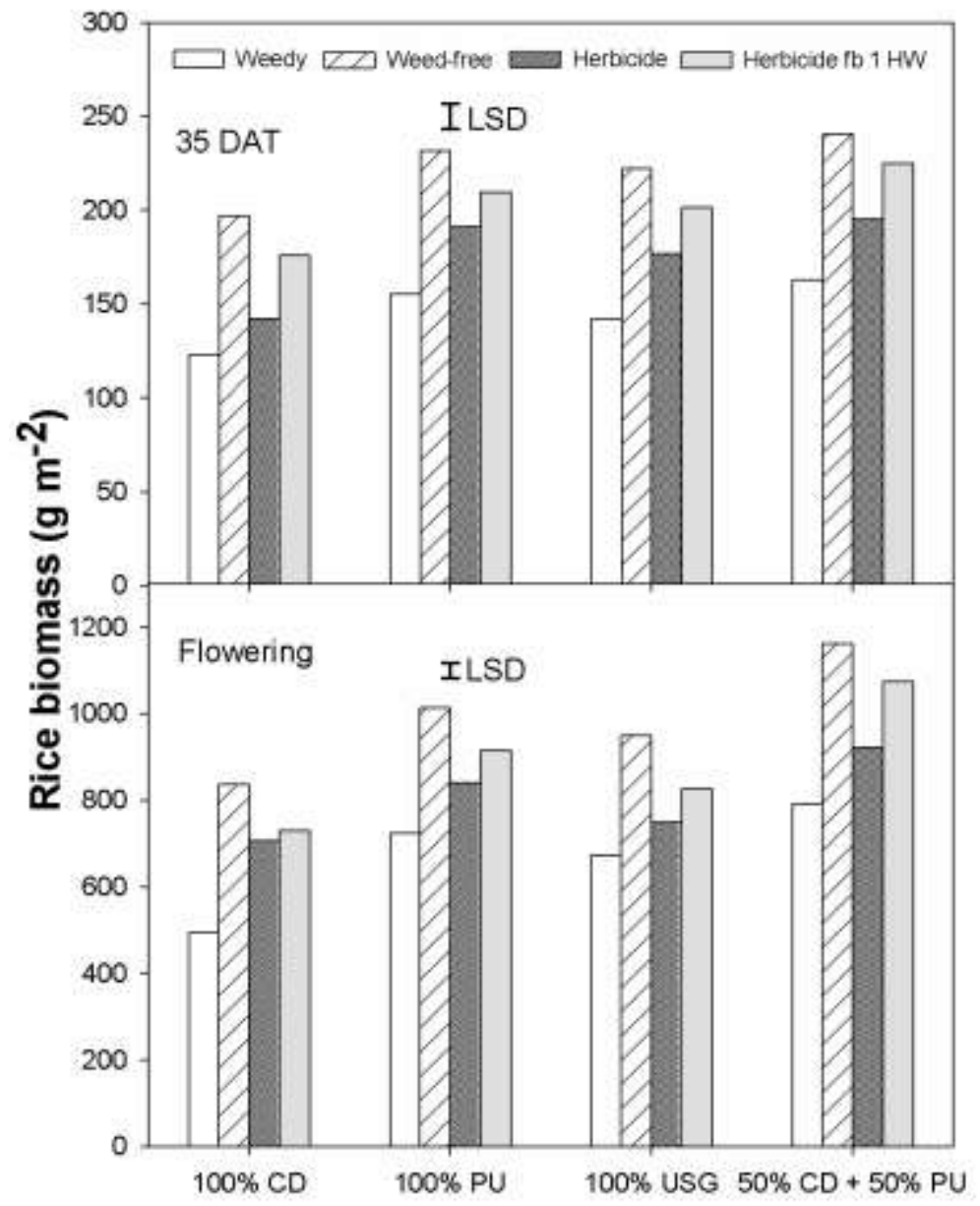

Nitrogen sources

Fig. 3. Effect of nitrogen sources and weed management options on rice biomass $\left(\mathrm{gm}^{-2}\right)$ at 35 DAT and at flowering. CD (Cowdung), PU (prilled urea), USG (Urea Super Granule). Vertical bars indicate LSD at 5\% level of significant. 
Ghosh et al.

\section{SPAD value}

SPAD value was significantly influenced by the interaction between $\mathrm{N}$ sources and weed management options (Figure 4). Considered with the N sources, at 35 DAT, the highest SPAD value was recorded when plots received $50 \%$ cowdung $+50 \%$ prilled urea. Plots received with $100 \%$ prilled urea had statistically similar SPAD value to $50 \%$ cowdung $+50 \%$ prilled urea. Plots received with 100\% cowdung produced the lowest SPAD value. In weed management options, weed-free treatment had always higher SPAD value. The treatment herbicide followed by $1 \mathrm{HW}$ had significantly similar SPAD value to weed-free treatment. The lowest SPAD value was recorded in weedy treatment. Similar to the result of 35 DAT, at flowering, SPAD value almost maintain similar trend. When rice plants had more competition with weeds, SPAD values decreased and it was due to both weed and rice plants shared the available resources (Awan et al., 2014).

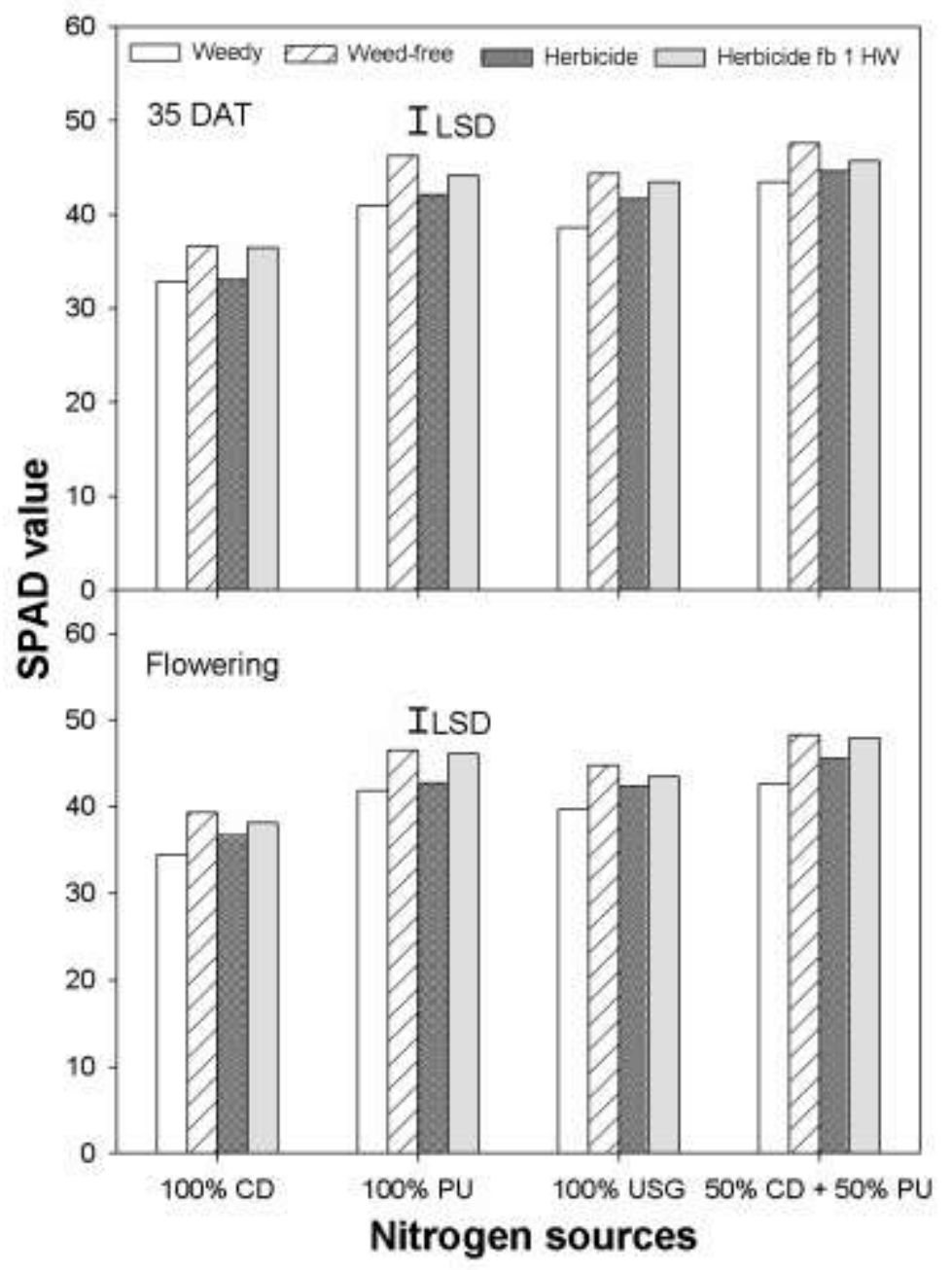

Fig. 4. Effect of nitrogen sources and weed management options on SPAD value at 35 DAT and at flowering. CD ( Cowdung); PU ( prilled urea),USG ( uUrea Super Granule). Vertical bars indicate LSD at 5\% level of significant. 


\section{Weed biomass}

The common weed species found in the experiment field were comprised of grasses (Cynodon dactylon, Echinochloa crusgalli, Leerisa hexandra, Paspalam scrobiculatum) broadleaf (Marselia guadrifolia, Monochoria vaginalis, Pistia stratioles) and sedges (Cyperus iria, Fimbristylis miliacea, Scirpus juncoides). Regarding the $\mathrm{N}$ sources, the highest total weed biomass was recorded when plots received 100\% prilled urea (Figure 5).

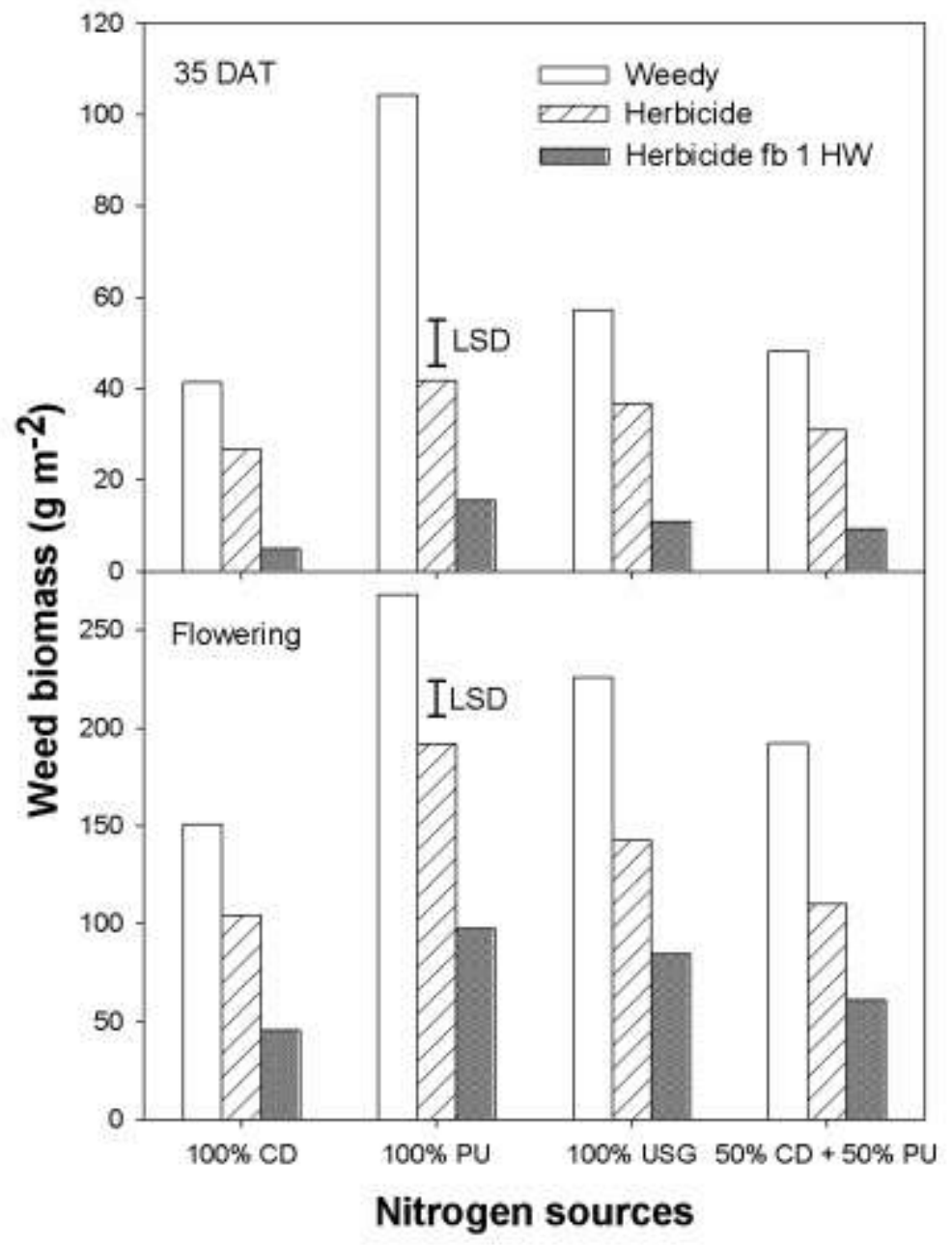

Fig. 5. Effect of nitrogen sources and weed management options on total weed biomass $\left(\mathrm{gm}^{-2}\right)$ at 35 D AT and at flowering. CD (Cowdung), PU (Prilled Urea), USG ( Urea Super Granule). Vertical bars indicate LSD at 5\% level of significant.

Irrespective of the weed control options, at 35 DAT, the nitrogen sources 100\% USG, 50\% cowdung $+50 \%$ prilled urea, and $100 \%$ cowdung had 54,46 and $35 \%$ lower weed biomass, respectively, compared with $100 \%$ prilled urea. These values were 46,35 and $19 \%$ at flowering. The dominant weed group found in the experiment was grass weed (Figure 6). 
Ghosh et al.

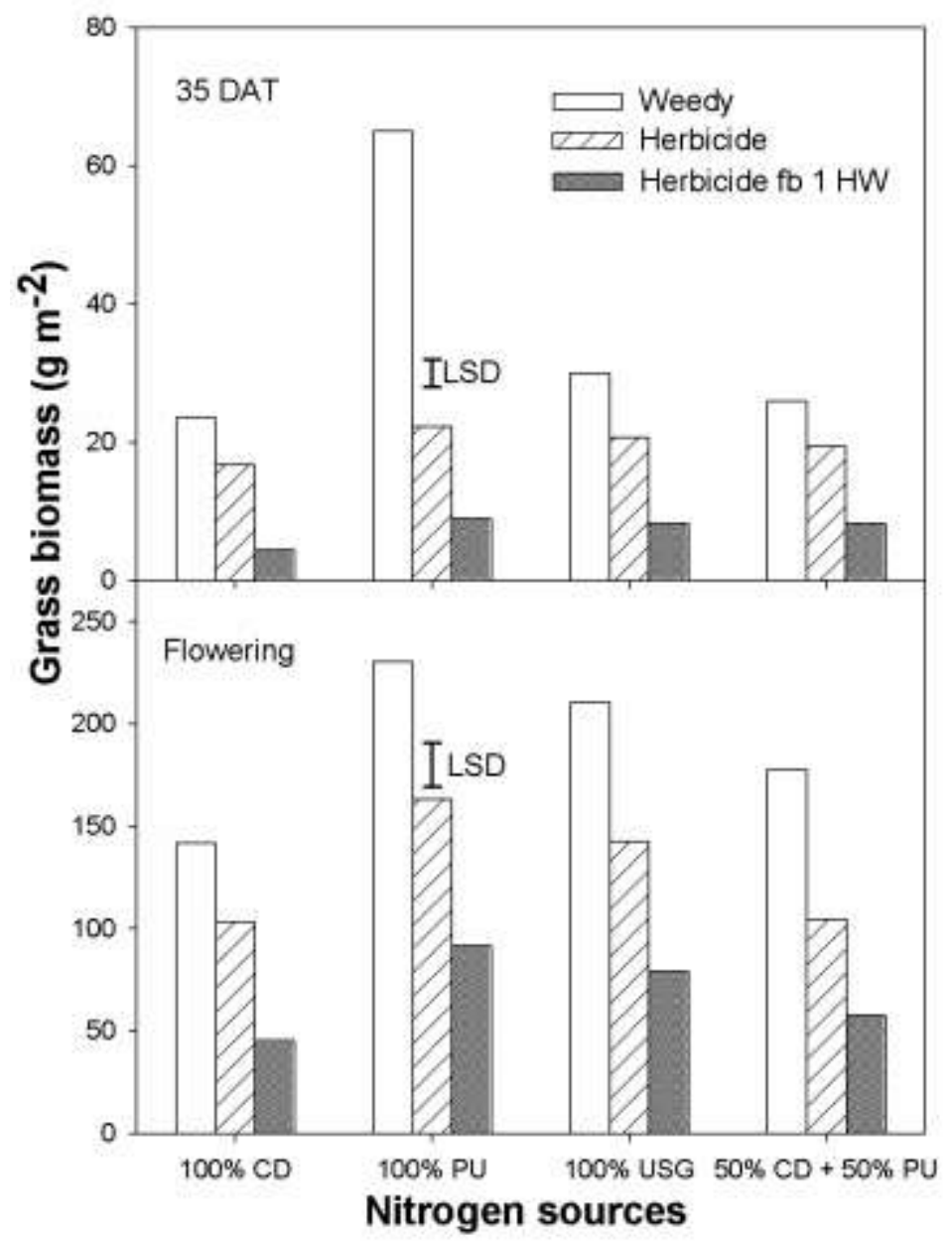

Fig. 6. Effect of nitrogen sources and weed management options on grass weed biomass $\left(\mathrm{g} \mathrm{m}^{-}\right.$ 2) at 35 DAT and at flowering. CD (Cowdung), PU ( Prilled Urea), USG (Urea Super Granule). Vertical bars indicate LSD at 5\% level of significant.

At 35 DAT, the highest grass weed biomass was found in nitrogen sources 100\% prilled urea treatment. In weed control options, the nitrogen sources 100\% USG, 50\% cowdung + 50\% prilled urea, and 100\% cowdung had 53, 44 and 39\% less grass weed biomass, respectively, compared with 100\% prilled urea treatment. Considered with the broadleaf weed, at 35 DAT, the season long weedy treatment of all nitrogen sources had similar biomass, however, at flowering $100 \%$ pill urea had significantly higher biomass than other nitrogen sources (Figure 7). Considered with the sedge weed, the highest weed biomass was recorded when plots received nitrogen source of $100 \%$ prilled urea and the lowest in $100 \%$ cowdung (Figure 8). When plots received weed control option herbicide followed by $1 \mathrm{HW}$, sedge biomass was almost zero. Similar effect at flowering stage which might be due to the shedding effect of rice canopy. As such prilled urea influenced weed growth better than other sources. The results were consistent with the previous study. ( Blackshaw, 2005; Kirkland and Beckie, 1998). 
Effect of Nitrogen Sources and Weed Management Options on Weed Growth and Crop Yield

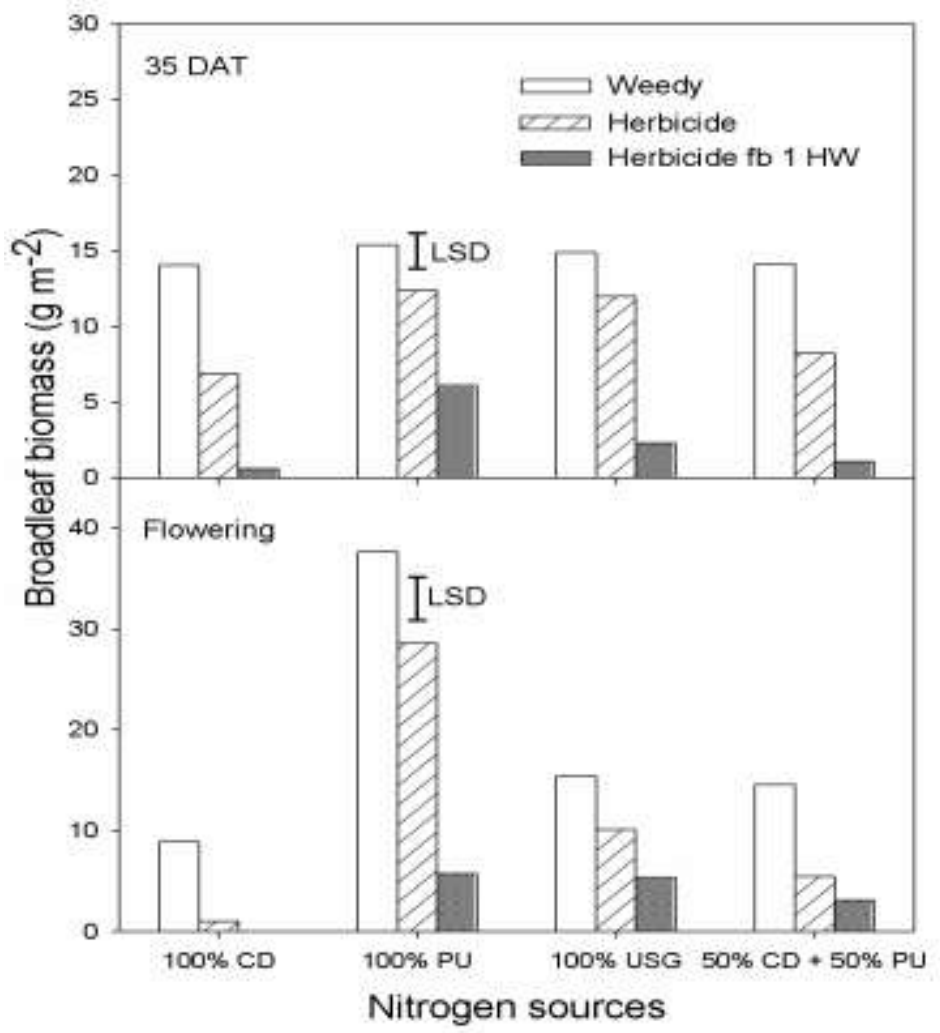

Fig. 7. Effect of nitrogen sources and weed management options on broadleaf weed biomass $\left(\mathrm{gm}^{-2}\right)$ at 35 DAT and at flowering. CD (Cowdung), PU (Prilled Urea), USG (Urea Super Granule). Vertical bars indicate LSD at 5\% level of significant.

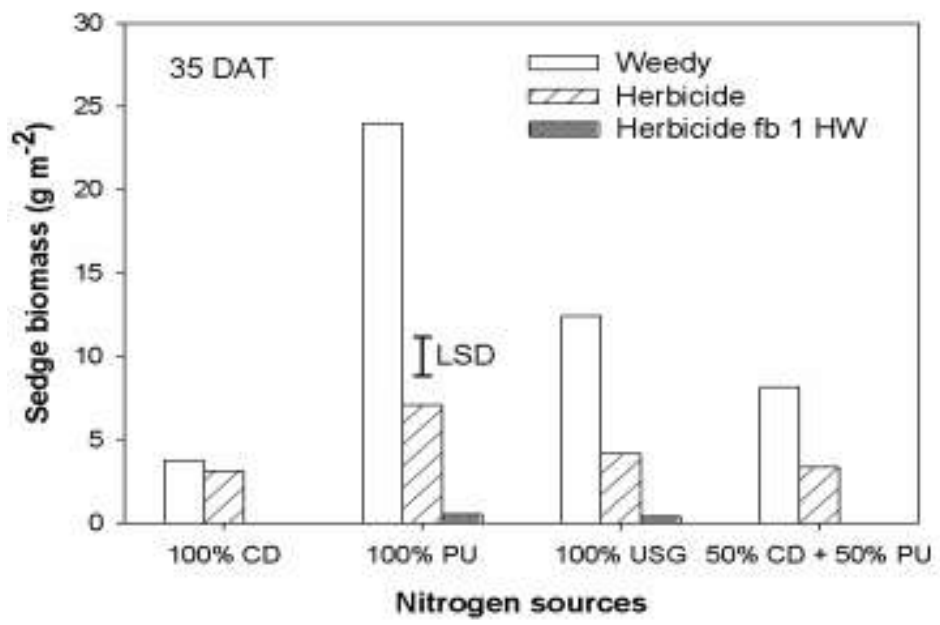

Fig. 8. Effect of nitrogen sources and weed management options on sedges biomass $\left(\mathrm{gm}^{-2}\right)$ at 35 DAT and at flowering. CD (Cowdung) PU (Prilled Urea), USG (Urea Super Granule). Vertical bars indicate LSD at $5 \%$ level of significant. 
Ghosh et al.

\section{Yield and yield components}

There was a significant interaction between $\mathrm{N}$ sources and weed management options on panicles number (Figure 9). In $\mathrm{N}$ sources, panicle number was always higher in weed-free by manual weeding. The weed management option herbicide followed by $1 \mathrm{HW}$ had significantly similar panicle number to weed-free treatment. Only herbicide treatment had similar panicle number to herbicide followed by $1 \mathrm{HW}$. In weed management options, the nitrogen source of $50 \%$ cowdung $+50 \%$ prilled urea had higher panicle number which was significantly similar to nitrogen source $100 \%$ prilled urea. Compared with 50\% cowdung $+50 \%$ prilled urea treatment, the nitrogen sources 100\% USG and 100\% cowdung had 10 and 19\% fewer panicle number, respectively. Effect of nitrogen sources and weed control option on florets panicle $e^{-1}$ was found that florets panicle $e^{-1}$ maintained almost similar trend to panicle number (Figure 10).

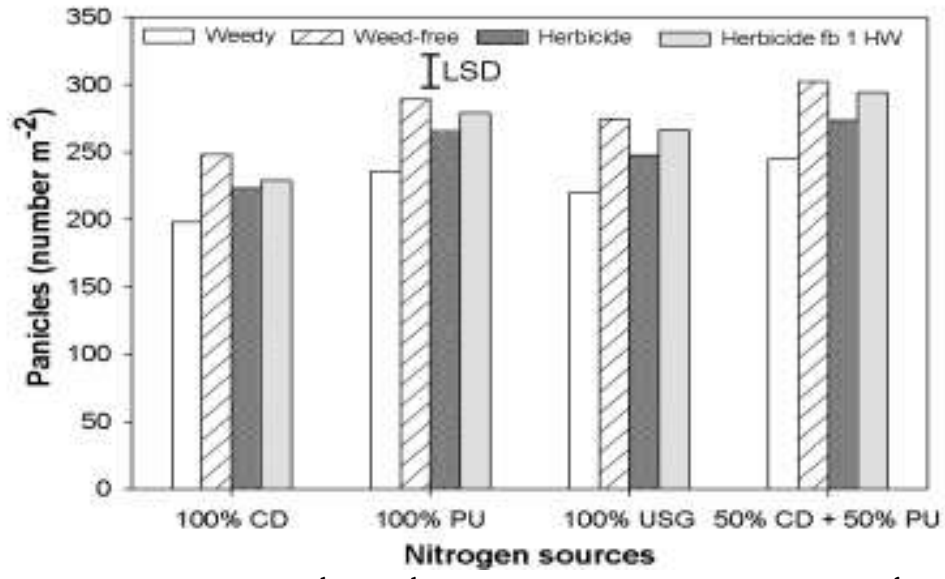

Fig. 9. Effect of nitrogen sources and weed management options on panicles (number $\mathrm{m}^{-2}$ ) at physiological maturity. CD (Cowdung); PU(Prilled Urea), USG (Urea Super Granule). Vertical bars indicate LSD at 5\% level of significant.

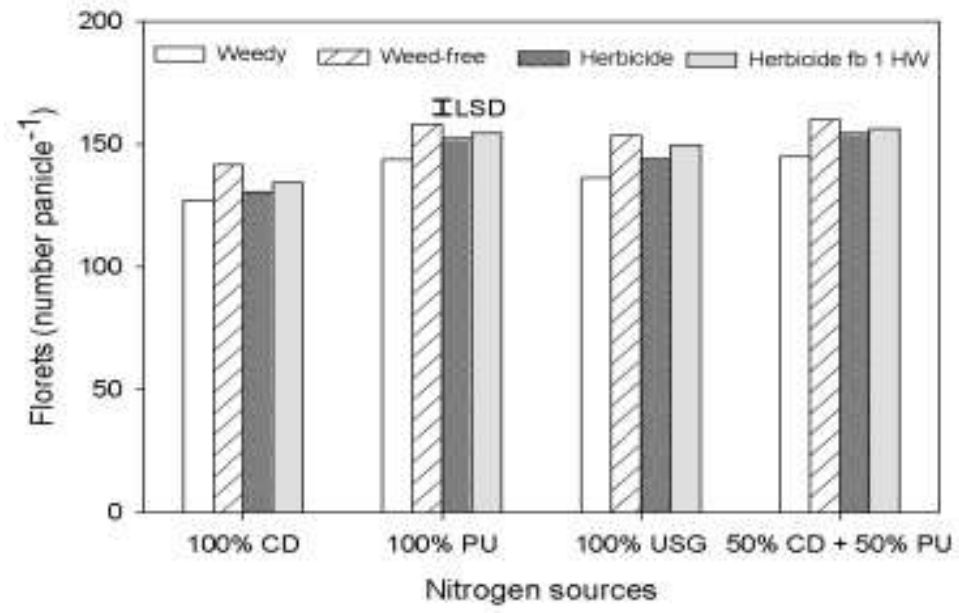

Fig. 10. Effect of nitrogen sources and weed management options on floret (numbers panicle ${ }^{-2}$ ) at physiological maturity. CD (Cowdung), PU (Prilled Urea), USG (Urea Super Granule). Vertical bars indicate LSD at 5\% level of significant. 
Grain and straw yields were also influenced by the interaction of nitrogen sources and weed management option. Irrespective of the weed management options, nitrogen source 50\% cowdung $+50 \%$ prilled urea had always higher grain and straw yield (Figure 11 and 12). Although $100 \%$ prilled urea had significantly similar grain and straw yield to $50 \%$ cowdung + $50 \%$ prilled urea, however, across the weed control options 100\% USG and 100\% cowdung had 15 and 27\% lower grain yield and 9 and 20\% lower straw yield, respectively. In nitrogen sources, the weed-free treatment had always higher grain and straw yield. Compared with weed-free treatment, the plots which received only herbicide had 20 and 18\% lower grain and straw yield, respectively.

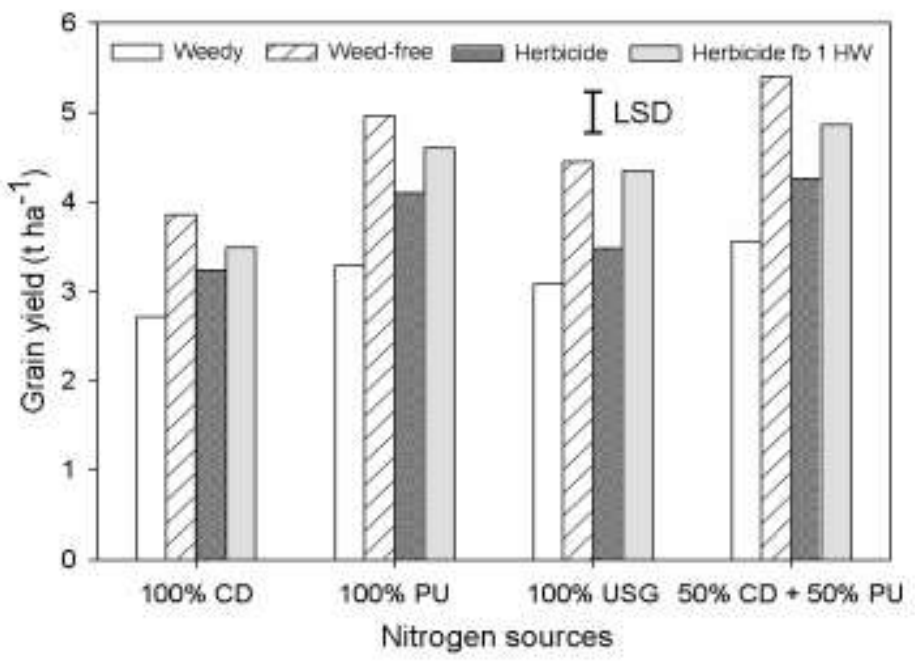

Fig. 11. Effect of nitrogen sources and weed management options rice grain yield ( $\mathrm{t}$ ha $\left.{ }^{-1}\right)$. CD (cowdung); PU (Prilled urea), USG (Urea Super Granule). Vertical bars indicate LSD at $5 \%$ level of significant.

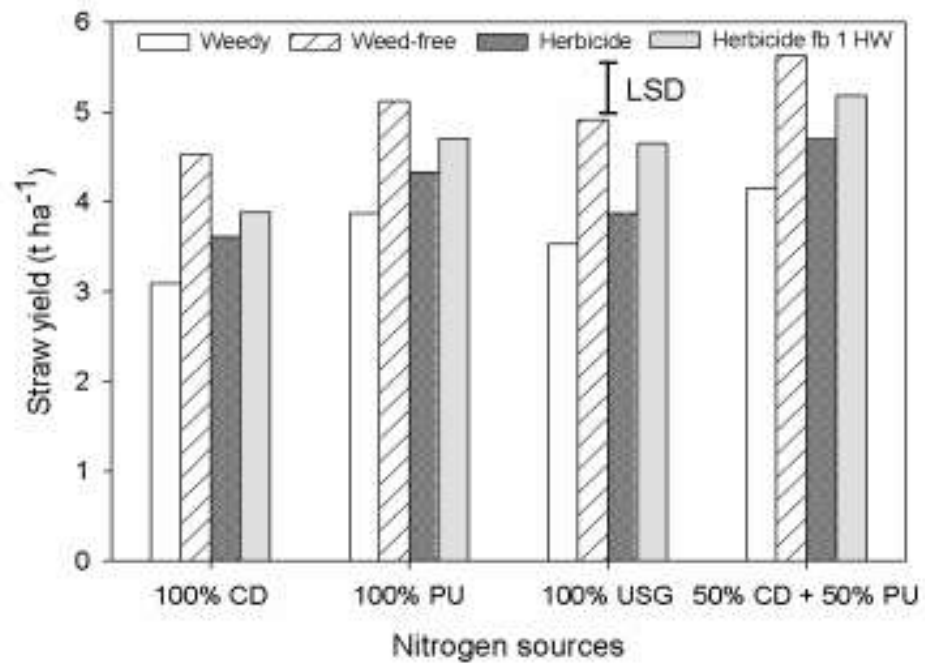

Fig. 12. Effect of nitrogen sources and weed management options on rice straw yield (t ha-1). CD (Cowdung), PU (Prilled Urea), USG (Urea Super Granule). Vertical bars indicate LSD at $5 \%$ level of significant. 
Ghosh et al.

Use of $100 \%$ prilled urea is better than the 100\% USG in terms of rice yield, however, prilled urea influence more weed growth than USG. So, the best N source was 50\% cowdung $+50 \%$ prilled urea. Although 100\% prilled urea had similar yield to 50\% cowdung $+50 \%$ prilled but $100 \%$ prilled urea stimulates weed growth. Pre-emergence herbicide followed by $1 \mathrm{HW}$ significantly controlled weed and found similar yield to weed free. Though maximum yield was obtained from weed free plot but it was not feasible due to high cost involvement of manual weeding. Therefore, the best weed management option is pre-emergence herbicide followed by one hand weeding.

\section{Conclusion}

Pre- emergence herbicides followed by on hand weeding (21DAS) is better weed management option for transplanted aman rice.

\section{Acknowledgment}

The authors would like to express their thanks to Agronomy Division, Bangladesh Agricultural University (BAU) for give opportunity to conduct this experiment.

\section{References}

Ahmed, S., M. Salim and B. S. Chauhan. 2014. Effect of weed management and seed rate on crop growth under direct dry seeded rice systems in Bangladesh. PLoS ONE 9 (7):10.1371/ journal.pone.0101919.

Ahmed, S. and B. S. Chauhan. 2014. Performance of different herbicides in dry-seeded rice in Bangladesh. Sci. World J. 10.1155 / 2014 / 729418.

Ahmed, S. and B. S. Chauhan. 2015. Efficacy and phytotoxicity of different rates of 0xadiargyl and pendimethalin in dry-seeded rice (Oryza sativa L.) in Bangladesh. Crop Prot. 72: 169-174.

Ahmed, S., T. H. Awan, M. Salim and B. S. Chauhan 2015. Economics of nitrogen and integrated weed management in dry seeded rice. J. Ani. Plant Sci. 25 (6) - 1675-1684.

Ali, M. A., J. K. Ladha, J. Rickman and J. S. Lales. 2006. Comparison of different methods of rice establishment and nitrogen management strategies for lowland rice. J. Crop Improv. 16: 173-189.

Anwar, M. P., A. S. Juraimi, A. Puteh, A. Man and M. M. Rahman. 2012. Efficacy, phytotoxicity and economics of different herbicides in aerobic rice. Acta Agric. Scandin. 62: 604-615.

Awan, T. H., B. S. Chauhan and P. C. S. Cruz. 2014. Growth plasticity of junglerice (Echinochloa colona) for resource use when grown with different rice (Oryza sativa) planting densities and nitrogen rates in dry-seeded conditions. Weed Sci. 62: 571-587.

BBS. 2013. Annual Report 2012-13. Bangladesh Bureau of Statistics. Ministry of Planning. Government of the People's Republic of Bangladesh, Dhaka. p. 238.

Blackshaw, R. E. 2005. Nitrogen fertilizer, manure, and compost effects on weed growth and competition with spring wheat. Agron. J. 97: 1612-1621. 
Effect of Nitrogen Sources and Weed Management Options on Weed Growth and Crop Yield

Chauhan, B. S., A. Ahmed, T. H. Awan, K. Jabran, and S. Manalil. 2015. Integrated weed management approach to improve weed control efficiencies for sustainable rice production in dry-seeded systems. Crop Prot. 71: 19-24.

Fageria, N. K., and V. C. Baligar. 2005. Enhancing nitrogen use efficiency in crop plants. Adv. Agron. 88: 97-185.

FAO. 2013. Statistical Yearbook. http://www.fao.org/docrep/018/i3107e/i3107e00.htm. Accessed: June 19.

FRG 2012. Fertilizer Recommendation Guide Bangladesh. Agricultural Research Council. Farmgate, New airport road, Dhaka 1215. p 274.

Fischer, A. J., C. M. Ateh, D. E. Bayer and J. E. Hill. 2000. Herbicide-resistant Echinochloa oryzoides and E. phyllopogon in California Oryza sativa fields. Weed Sci. 48: 225-230.

Hasanuzzaman, M., K. Nahar, T. S. Roy, M. L. Rahman, M. Z. Hossain and J. U. Ahmed. 2009. Tiller dynamics and dry matter production of transplanted rice as affected by plant spacing and number of seedling per hill. Acad. J. Plant Sci. 2:162-168.

IRRI. 1998. International Rice Research Institute. Annual Report for 1997. Los Bañs, Laguna, Philippines. p. 246.

Kirkland, K. J. and H. J. Beckie. 1998. Contribution of nitrogen fertilizer placement to weed management in spring wheat (Triticum aes- tivum). Weed Technol. 12: 507-514.

Rao, A. N., D. E. Johnson, B. Sivaprasad, J. K. Ladha, and A. M. Mortimer. 2007. Weed management in direct seeded rice. Adv. Agron. 93: 153-255.

Raun, W. R. and G. V. Johnson. 1999. Improving nitrogen use efficiency for cereal production. Agron. J. 91: 357-363.

Raun, W. R., G. V. Johnson, M. L. Stone, R. W. Mullen, K. W. Freeman, W. E. Thomason and V. Lukina. 2002. Improving nitrogen use efficiency in cereal grain production with optical sensing and variable rate application. Agron. J. 94: 815-820.

Salam, M. A., F. Ali, M. P. Anwar and M. S. U. Bhuiya. 2004. Effect of nitrogen level and date of transplanting on the yield and yield attributes of transplanted Aman rice under SRI method. J. Bangladesh Agril. Univ. 2: 31-36.

Singh, S., L. Bhushan, J. K. Ladha, R. K. Gupta. A. N. Rao and B. Sivaprasad. 2006. Weed management in dry seeded rice cultivated on furrow irrigated raised bed planting system. Crop Prot. 25: 487-495.

Sudhir-Yadav, G. Gill, E. Humphreys, S. S. Kukal and U. S. Walia. 2011. Effect of water management on dry seeded and puddled transplanted rice. Part 1: Crop performance. Field Crops Res. 120: 112-122. 